Rebecca-Anne Do Rozario, Nike Sulway and Belinda Calderone

\title{
Introduction: The state of play in Australian fairy tale: Where to now?
}

At the turn of the last century, writers like Atha Westbury and Hume Cook were asking whether Australia had its own fairies, its own fairy tale lore. They attempted to fill the perceived lack of traditional fairy-tale narratives with their own published works of fairy tale. The titles authors chose for their collections - for instance, Olga Ernst's Fairy tales from the land of the wattle and Annette Kellermann's Fairy tales of the south seas and other stories - often revealed an overt wish to build a fairy-tale tradition that was distinctly and uniquely Australian. While some of these tales simply relocated existing European tales to the Australian context, most used classic fairy-tale tropes and themes to create new adventures. Other writers and collectors, like K Langloh-Parker, Sister Agnes and Andrew Lang, sought to present Indigenous tales as examples of local folk and fairy tales - a project of flawed good intentions grounded in colonial appropriation. These early Australian publications are largely forgotten and, in many ways, the erasure or forgetting of narratives that were often infused with colonial attitudes to gender, class, race, is far from regrettable. And yet there was a burgeoning local tradition of magical storytelling spearheaded by the delicate fairies of Ida Rentoul Outhwaite's brush and the gumnut babies of May Gibbs that celebrated the Australian environment, its flora and fauna, populating and decorating new tales for the nation's children.

In the last few decades, there has been little discussion of what might constitute an Australian fairy-tale tradition or practice, although there have been lauded attempts to create or continue them, including Murray Bail's novel, Eucalyptus (1998), often cited as an example of a contemporary Australian fairy tale. However, a broad, diverse engagement with fairy tale has nevertheless been evolving in Australia's writing and storytelling community. It often goes unrecognised, in part because the popular notion of a fairy tale is so strongly linked to the traditional, European tales, especially those collected by the Brothers Grimm. Shadowed in this history, writers who employ fairytale motifs and tropes, retell earlier tales or create original fairy tales, are often perceived as engaging with a largely European tradition. Their work is seen as a looking back, rather than as a forward-looking, radical, innovative or experimental intervention in a genre that has a long history of continual reinvention and relocation. Writers known for their fairy-tale work are thus frequently understood as in conversation with the past, rather than with the contemporary world, or the future. And yet, even during the last century, writers working within the European tradition engaged in a looking-back that was not merely nostalgic, but also critical and political: conscious of the ways in which these pervasive tales informed contemporary culture and identity. Some of the major fairy-tale works of the twentieth century, such as those of Angela Carter, Anne Sexton, and Margaret Atwood, were explicit feminist critiques of canonical fairy tales, helping to cement the notion that new fairy tales always look backwards to engage with older 
tales, while simultaneously looking forward, or at least sideways, towards a new way of understanding or embodying fairy-tale themes such as marriage, sexuality and animality. Fairy-tale works are also largely considered in terms of their relation to genres such as historical fiction, romance, young adult fiction or speculative fiction, rather than as in conversation with each other, or with the international or even national field of fairy-tale practice. Perhaps partly because of these kinds of issues around the discomfort of claiming or creating a contemporary fairy-tale tradition, we have been slow to recognise our own Australian fairy-tale tradition as it matures.

Internationally, however, new works are being accepted as contemporary fairy tale. Bill Willingham's Fables series (2002-2015) exploited metafictional potential in the fairytale tradition, as did television shows like the $\mathrm{ABC}$ 's Once upon a time. The fairy-tale works of Neil Gaiman, most recently, The Sleeper and the spindle (2014), achieve popular success. A collection like Parisien and Wolfe's The Starlit wood: New fairy tales (2016) is upfront about its genre, as well as its current relevance, and has garnered critical acclaim. Meanwhile, Michael Cunningham's A wild swan: And other tales (2015) has been presented as a collection of fairy tales for our time. And these new fairy-tale works are increasingly gaining recognition. In their categories, C.S.E. Cooney's Bone swans: stories won the 2016 World Fantasy Award, Amal El-Mohtar's 'Seasons of glass and iron' won the 2017 Locus and Awards, Theodora Goss's 'Rose child' won the 2017 Rhysling Award, and Naomi Novik's Uprooted won the 2016 Nebula, Locus and Mythopoeic Awards. On our home soil, local writers such as Carmel Bird, Sophie Masson, Kim Wilkins, Angela Slatter, Danielle Wood, Allyse Near, Margo Lanagan, Lisa L Hannett, Kirstyn McDermott, Angie Rega, Kathleen Jennings and Kate Forsyth - and many more - have all published both short stories and novels that draw on the fairy-tale tradition within the last decade, demonstrating the vitality of the genre within the national writing community. And while many of these works draw overtly and explicitly on European fairy-tale traditions, they are rarely simple retellings. Instead, they often grapple with the relationship - and tension - between European fairy-tale traditions and the Australian context. Angie Rega's 'The bush bride of Badgery Hollow' (2015) tells a haunting tale of a man who tries to conquer a sugar glider bush bride - evoking the tension between Australia's settlers and native inhabitants. Indigenous author Alexis Wright uses fairy-tale storytelling elements in The swan book (2013) to present a dystopian Australian future that highlights many of today's struggles for the Indigenous community. Many of these Australian writers, too, have won both national and international awards, including our contributor, Kate Forsyth, who won the American Library Association Award for Best Historical Novel for her Rapunzel-inspired work, Bitter greens, in 2015. Such recognition is a clear indicator of the rude health of the genre, and of the calibre of the writing it generates.

In our own research and writing, and in our participation in the Australian Fairy Tale Society, we are manifestly aware of how fairy tale is becoming prominent in the works of Australian authors and scholars. Griffith Review published a special edition, Once upon a time in $\mathrm{Oz}$, in 2013, and in 2015/2016, The Victorian Writer released a fairytale issue. Each year, too, the Australian Fairy Tale Society hosts an annual conference, bringing together scholars, researchers, writers and visual artists as well as digital and oral storytellers. In spite of the interdisciplinary, multidisciplinary and transnational 
impact of fairy-tale writing and research, the focus of much previous scholarly and critical work has often been the European traditions, including their influence on contemporary literature. This work has also largely focused on texts produced in and reflective of the cultural and literary focus of Europe and the United States, with little to no attention to contemporary storytelling traditions, or to writers working in the Australasian context. We saw a need, therefore, for a special issue that would engage with the particular historical and contemporary research and practice of the fairy tale in Australia. We have drawn together a wide range of researchers, writers and other practitioners whose work explores the particular challenges and possibilities of the Australasian fairy tale. The papers in this issue include research into the fairy-tale tradition within Australia, seeking to understand the tales that came before, including tales that might yet suggest fresh possibilities for creative engagement, as well as researchers and writers examining current critical and creative practice. We have writers who are finding new ways of forging Australian fairy tale, and sometimes reembracing the traditional to explore its promise in the contemporary world.

We have included original and reimagined fairy tales that cross over into children's literature - often misunderstood as the proper or traditional realm of the fairy tale evoking apparent, often duplicitous simplicity, such as Sherryl Clark's 'The handkerchief of tears' and Sophie Masson's 'A feather of Fenist the Falcon'; tales that evoke the fanciful and the peculiar, like Louisa John-Krol's 'Envoys to the empress'; and tales that take a darker, more adult or experimental tone, such as Danielle Wood's 'The Blackaby Road' and Daniel Baker's 'Facets of Eleanor.' Kate Forsyth also revisits her doctoral project on Rapunzel in 'Retelling Rapunzel,' the exegesis having recently been published by FableCroft and reviewed here by Belinda Calderone.

Danielle Wood explores the multifaceted ways in which Australian writers approach the genre in her article, 'Strategic, stylistic and notional intertextuality: Fairy tales in contemporary Australian fiction,' providing an overview of writers' engagements with fairy tale as a literary device. Kirstyn McDermott investigates the specific opportunities available in fairy tale's emphasis upon the relationships between women in 'There is always a next witch: Creative intuition and collaborative female relationships in fairy tales.' Michelle De Stefani's 'Taming the Hobyahs: Adapting and re-visioning a British tale in Australian literature and film' explores the way British narrative traditions are absorbed into and rendered unique in an Australian context. Louisa John-Krol, who brings with her a long history in fairy performance and fairy-inspired music, presents her reflections on the intertwined histories of fairy- tale storytelling and community, and how the fairy tale, in many forms, bubbles up in the Australian creative psyche in 'Fated intervention: Gracing, musing and the wishing well'.

Looking to the history of Australian fairy tale, Robyn Floyd reveals how the tales contributed to the project of national identity in 'Fairies in the bush: The emergence of a national identity in Australian fairy tales,' while Catherine Snell presents the case for the genre's relationship to environmentalism and education policy in 'Of education, the bush, and other strange creatures: Environmental conservation in Australian fairy tales.' In better understanding the past, these articles shed light upon where today's authors can go. 
Rebecca-Anne Do Rozario also interviews Lorena Carrington, whose artwork inspired Wood's 'The Blackaby Road', and who has recently collaborated with Kate Forsyth on a new work of Australian fairy tales, Vasilisa the wise and other tales of brave young women, to be released later this year by Serenity Press. Australian fairy tale has a rich pictorial tradition, and in this interview the scholar/writer and illustrator discuss the close relationship between writing and illustrating fairy tale and how both respond to the significance of landscape.

Each article approaches the tradition of the fairy tale from a unique perspective, offering multiple ways to understand or conceptualise the notion of an Australian fairy-tale practice. Each of the writers featured here responded with dynamic and passionate energy to our call for papers exploring the theme of the Australasian Fairy Tale. We hope you are stimulated, titillated, cursed, spelled or transported by them, and that, as a body of work, they both enrich your understanding of the scope and possibilities of the fairy tale in Australasia and inspire you to weave your own critical and creative spells. In the words of the contemporary fairy-tale teller, Emma Donoghue: This is the story you asked for. I leave it in your mouth.

Dr Nike Sulway is a Senior Lecturer in the School or Arts and Communication at the University of Southern Queensland. She is the author of Dying in the first person, Rupetta, The bone flute, The true green of hope, and What the sky knows, as well as the forthcoming children's book Winter's tale. Her works have won or been shortlisted for a range of national and international awards, including the Tiptree Award, the QLD Premier's Literary Award, the Commonwealth Writers Award, the Children's Book Council of Australia's Book of the Year Awards, the IAFA Crawford Award, the Aurealis Awards and the Norma K Hemming Award. She is also the author of a number of published and forthcoming essays and chapters on contemporary women writers, including essays on Lyn Palmer, Barbara Newhall Follett and James Tiptree, Jr. Nike is a contributing co-editor of the forthcoming book Forgotten lives: Recovering history through fact and fiction (Cambridge Scholarly Publishing). She will be a Guest of Honour at the 2018 International Conference for the Fantastic in the Arts, alongside John Kessel and Fred Botting.

Dr Rebecca-Anne C Do Rozario has been teaching fairy tales and speculative fiction at Monash University for the past decade. She has published essays and chapters on topics including Disney princesses, Wizard Rock, Terry Pratchett's witches, and Victorian pantomimes. She has also published the occasional short story including 'The death of Glinda, the good witch' in Aurealis Magazine. Her book, Fashion in the fairytale tradition: What Cinderella wore, will be coming out with Palgrave.

Dr Belinda Calderone holds a PhD in Literary Studies from Monash University. Her thesis examined how representations of motherhood changed over time in European fairy-tale history. She has spoken at conferences and taught at universities - often in fantasy and children's literature. Her publications include a book chapter, 'The monster inside me: Unnatural births in early modern Italian and French fairy tales' in 
Beyond the monstrous: Reading from the cultural imaginary. She is also Past President of the Australian Fairy Tale Society. 